\title{
Detection of equine infectious anemia nucleic acid in asymptomatic carrier horses by nested PCR
}

\author{
Sunutcha Suntrarachun ${ }^{\mathrm{a}}$, Surasak Akesowan ${ }^{\mathrm{a}}$, Thaweesak Tirawatnapong ${ }^{\mathrm{b}}$, Orawan Khow ${ }^{\mathrm{a}}$ \\ ${ }^{a}$ Queen Saovabha Memorial Institute, Thai Red Cross Society, Bangkok 10330; ${ }^{b}$ Faculty of Medicine, \\ Chulalongkorn University, Bangkok 10330, Thailand
}

\begin{abstract}
Background: Equine infectious anemia virus (EIAV) is a lentivirus with an almost worldwide distribution, infecting equids. It causes a persistent infection that is characterized by recurring episodes of fever, anemia, and thrombocytopenia. Most of the horses may control EIAV replication within a year, remaining persistently infected without clinical signs of disease.

Objective: Detect EIA nucleic acid from peripheral blood of asymptomatic horses using nested PCR.

Materials and method: We used nested PCR, amplifying P26 gag gene of EIAV, for direct detection of viral RNA in plasma and proviral DNA from PBMC in asymptomatic carrier horses in comparison with the Coggins test. EIA nucleic acid was prepared from 20 seropositive and five EIAV seronegative horses. Amplification of 246 bp expected size fragments was obtained using two different sets of primers targeting the P26 gag gene.

Results: Among 20 seropositive horses, nine samples were positive for RNA and DNA. The five samples were positive for DNA but not for RNA, which indicates that the virus integrated into the host cell genome with a low level of viral replication. However, six samples were negative for both DNA and RNA. False negative could result due to primer failure caused by gag sequences variation among strains circulating in Thailand when compared with various strains from other parts of the world. EIAV antigens may also be prepared from cell cultures contaminated with other retroviruses thus causing false positives with the Coggins test.

Conclusion: Nested PCR can be a useful tool for detecting the presence of EIAV in asymptomatic carrier horses. This may be especially true during the acute stage of the disease where the viremia levels are usually at the highest levels before detectable antibodies appear.
\end{abstract}

Keywords: Proviral DNA, PBMC, viral nucleic Acid, viral RNA

Equine Infectious Anemia Virus (EIAV) is a member of the genus Lentivirus of the Retroviridae family. It is distributed worldwide and has only been reported in equids. EIAV is a close relative of the human immunodeficiency virus (HIV) with which it shares many structural and biochemical features [1].

EIAV was first recognized in Thailand in 1983. It was identified in the Northeast, North, and West Thailand. In a serological survey of the North (Lumpang province) in 2001 and 2006, less than 10\%

Correspondence to: Sunutcha Suntrarachun, Department of Research and Development, Queen Saovabha Memorial Institute, The Thai Red Cross Society, 1871 Rama IV Rd, Patumwan, Bangkok 10330, Thailand. E-mail: sunutcha@yahoo.com of horses (4.2\% and 6.9\%) were EIAV positive. The disease has never been identified in South and Eastern Thailand and has been recorded as sporadic. Horses have been diagnosed using the Coggins test. Testing has been performed mainly in race horses because of the requirements of the Thailand Equestrian Federation. Other horses have never been submitted to this test due to the high cost [2].

The agar gel immunodiffusion assay (AGID or Coggins test) is widely accepted for serological detection of the EIAV specific antigen p26 [3]. In addition, the competitive enzyme linked immunosorbent assay (c-ELISA) and synthetic antigen ELISA (SAELISA) have been used for serological detection of EIA specific antibodies. In the USA, detection of EIAV antibodies by fluorescent polarization based 
assay has been reported. Virus isolation is not practical because it is time consuming, laborious, and requires special technical skills to maintain primary horse macrophage cultures for replication of pathogenic EIAV. PCR is likely to be sensitive and specific for the detection of EIAV proviral DNA in blood cells. This technique can diagnose subclinical EIAV infection and recently infected horses in the process of mounting an immune response. Furthermore, infected foals with colostral anti-EIAV antibodies could be identified $[4,5]$.

In this study, we developed an EIAV specific nested PCR assay using two different sets of primers in the gag region for direct detection of viral RNA in plasma and proviral DNA from peripheral blood mononuclear cell (PBMC) of asymptomatic carrier horses. The assay was performed in parallel with the serological Coggins test, the standard diagnostic method. Nested PCR could be considered as an alternative method for detection of EIAV infection in asymptomatic horses.

\section{Materials and methods Animal samples and viruses}

The animals used in this study were 25 apparently healthy horses of 2-15 years old. Twenty of them were seropositive for EIA antibodies using the agar gel immunodiffusion test (AGID or Coggins test) while the other five horses were seronegative. EDTA blood was collected for isolation of plasma, peripheral blood mononuclear cell (PBMC) and Coggins test. DNA from pathogenic strains including EIAVpathogenic variant, EIAVwyoming, EIAVv26, and EIAVliaoning were used as positive controls.

\section{Nucleic acid extraction}

Viral RNA was extracted using Trizol reagent
(Molecular Research Center, Inc, Cincinnati, Ohio, USA). Separation of PBMC from EDTA blood samples was performed by Ficoll-Paque ${ }^{\mathrm{TM}}$ Plus (GE Healthcare, Uppsala, Sweden). The buffy coat containing PBMC was then extracted for proviral DNA using QIAmp DNA extraction kit (Qiagen, Valencia, USA).

\section{Nested PCR amplification}

Two different sets of primers based on nucleotide sequences of EIAV gag gene, which is widely accepted as being highly conserved, were designed from the reference strain (NC_001450) and Liaoning strain (AF327877). Nucleotide sequence and relative positive of the synthetic oligonucleotide primers were shown in Table 1.

RT-PCR was carried out with 30 L reaction buffer containing $5 \times 1$ st strand synthesis buffer, $100 \mathrm{mM}$ each dNTP, $25 \mathrm{mM} \mathrm{MgCl}_{2}, 100$ u MMLV reverse transcriptase, $50 \mathrm{pmol} / \mu \mathrm{L}$ antisense primer and $1 \mu \mathrm{g}$ RNA template. The amplification was preceded on a thermocycle (MWG Biotech, USA) at $37^{\circ} \mathrm{C} 30$ minutes, $95^{\circ} \mathrm{C}$ five minutes. Then, $20 \mathrm{~L}$ of the first PCR reaction was added to the $\mathrm{RT}$ reaction which consists of 10xbuffer, $100 \mathrm{mM}$ each dNTP, $25 \mathrm{mM}$ $\mathrm{MgCl}_{2} 50 \mathrm{pmol} / \mu \mathrm{L}$ sense primer and DNA polymerase $5 \mathrm{U} / \mu \mathrm{L}$. The reaction was carried out at $94^{\circ} \mathrm{C} / 55^{\circ} \mathrm{C} /$ $72^{\circ} \mathrm{C}$ one minute each, for a total of 35 cycles. PCR reaction was carried out with $50 \mu \mathrm{L}$ reaction containing 10xbuffer, each dNTP of $100 \mathrm{mM}, 25 \mathrm{mM} \mathrm{MgCl}, 50$ $\mathrm{pmol} / \mu \mathrm{L}$ sense and antisense primers, Taq DNA polymerase and $10 \mu \mathrm{L}$ DNA template. The first cycle conditions for flanking primers consisted of initial denaturation at $94^{\circ} \mathrm{C}$ for three minutes followed by $94^{\circ} \mathrm{C}$ for one minute, $56^{\circ} \mathrm{C}$ for one minute, $72^{\circ} \mathrm{C}$ for one minute for 40 cycles with final extension of $72^{\circ} \mathrm{C}$ for seven minutes.

Table 1. Oligonucleotide primers used in the nested RT-PCR and nested PCR of gag region sequences from EIAV (Based on the sequence NC_001450 and AF327877).

\begin{tabular}{llll}
\hline Primer & Sequence $\left(\mathbf{5}^{\prime} \rightarrow \mathbf{3}^{\prime}\right)$ & $\begin{array}{l}\text { Position in } \\
\text { EIAV } \\
\text { genome }\end{array}$ & $\begin{array}{l}\text { Product } \\
\text { size (bp) }\end{array}$ \\
\hline Flanking primers & AATGAATGCATTTTTGGATGT & $1052-72$ & 498 \\
P26-F & CATGCATACATTTCTCTTCT & $1529-1549$ & \\
P26-R & & $1184-1205$ & 246 \\
Inner primers & ACAAGGGCCTATTCCCATGACA & $1408-1429$ & \\
P26-FN & GGATGTCCCTCACTTTTATCT & & \\
P26-RN & & & \\
\hline
\end{tabular}


Nested PCR was carried out with $5 \mu \mathrm{L}$ from the first reaction sample as template with inner primers. The second amplification cycle conditions consisted of initial denaturation at $94^{\circ} \mathrm{C}$ for 2 minutes followed by $94^{\circ} \mathrm{C}$ for one minute, $56^{\circ} \mathrm{C}$ for 30 seconds, $72^{\circ} \mathrm{C}$ for one minute for 35 cycles and a final extension of $72^{\circ} \mathrm{C}$ for seven minutes. The final products were electrophoresed on a $2 \%$ agarose gel containing ethidium bromide in $1 \mathrm{x}$ TAE buffer along with appropriate molecular size markers.

\section{Agar gel immunodiffusion test (AGID or Coggins test)}

The commercial DiaSystems EIA agar gel immunodiffusion kit (DEXX Lab, Maine, USA) was used to detect antibodies against p26 protein of EIAV. Samples were set up according to the manufacturer instructions. The agar gel immunodiffusion test was considered valid if the positive controls in each plate showed expected results.

\section{DNA sequencing}

Cycle sequencing was performed using PerkinElmer Big Dye Terminator reaction. The PCR reaction was carrier out in a $20 \mu \mathrm{L}$ reaction mixture containing $4 \mu \mathrm{L}$ of terminator ready reaction mix, $5 \mathrm{pmol}$ sequencing primer and 60 ng DNA template. Cycle parameters were: $96^{\circ} \mathrm{C}$ for 10 seconds, 25 cycles of $96^{\circ} \mathrm{C}$ for 10 seconds $/ 50^{\circ} \mathrm{C}$ for 5 seconds $/ 60^{\circ} \mathrm{C}$ for four minutes. DNA was precipitated using DyeEx 2.0 Spin kit (Qiagen, Valencia, USA) and dried in a vacuum centrifuge for 15-20 minutes. The pellet was resuspended in 10 L Template Suppression Reagent (Perkin-Elmer) and loaded to the ABI PRISM sequencer.

\section{Results}

Twenty-five EDTA samples from 20 seropositive and five seronegative for EIAV antibody horses were collected, extracted for viral RNA and proviral DNA and the Coggins test was performed. Nine horses of the 20 seropositives were positive for gag gene for both RNA in plasma and DNA in PBMC, whereas 6 out of 20 seropositives were negative for both RNA and DNA by nested PCR. Only five proviral DNA from 20 seropositives but not viral RNA generated 246 bp of expected size using nested PCR (Table 2).

Table 2. Detection of viral RNA in plasma and proviral DNA in PBMC of 25 horses using P26 as primers compared with Coggins test.

\begin{tabular}{|c|c|c|c|}
\hline $\begin{array}{c}\text { Horse } \\
\text { number }\end{array}$ & $\begin{array}{l}\text { RNA } \\
\text { plasma }\end{array}$ & $\begin{array}{c}\text { DNA } \\
\text { PBMC }\end{array}$ & $\begin{array}{l}\text { Coggins test } \\
\text { antibody }\end{array}$ \\
\hline 1 & - & - & - \\
\hline 2 & - & - & - \\
\hline 3 & - & - & - \\
\hline 4 & - & - & - \\
\hline 5 & - & - & - \\
\hline 6 & + & + & + \\
\hline 7 & - & + & + weak \\
\hline 8 & + & + & + \\
\hline 9 & - & - & + weak \\
\hline 10 & + & + & + \\
\hline 11 & + & + & + weak \\
\hline 12 & - & + & + weak \\
\hline 13 & - & + & + weak \\
\hline 14 & - & - & + \\
\hline 15 & - & - & + weak \\
\hline 16 & + & + & + \\
\hline 17 & + & + & + \\
\hline 18 & - & + & + weak \\
\hline 19 & - & - & + \\
\hline 20 & - & + & + weak \\
\hline 21 & + & + & + weak \\
\hline 22 & - & - & + weak \\
\hline 23 & - & - & + weak \\
\hline 24 & + & + & + \\
\hline 25 & + & + & + weak \\
\hline
\end{tabular}


As positive controls were not available in Thailand, DNA from pathogenic strains EIAVpv, EIAVwy, EIAVv26, and EIAVlia were provided as positive controls from the United States, Japan and P. R. China. Nucleotide sequencing of PCR products derived from PBMC of different horses were performed. The results were deposited in the NCBI GenBank with three different isolates under accession number FJ713789 (Tha1), FJ713790 (Tha2), and FJ713791 (Tha3). The phylogenetic tree showing relationships of EIAV strains based on the gag gene in public database and three isolates (Tha1, Tha2, and Tha3) in this study were presented in Fig. 1.

\section{Discussion}

Conventional serodiagnostic assays, for detection of anti- EIAV antibodies, are convenient and useful for large-scale screening but these tests possess certain limitations. The most obvious limitation is the inability to detect EIAV during the early stage of infection where anti-EIAV antibodies are either absent or present but in an amount not detectable by the Coggins test. This could lead to false interpretation as negative result. Of importance is that these horses could serve as an important source of EIAV transmission because plasma viraemia is usually present [6].

In this study, viral RNA and proviral DNA could be detected by nested PCR in both plasma and PBMC of most seropositive horses. Meanwhile, only proviral DNA in PBMC of some samples could be detected. This is due to the virus being integrated into the host cell genome DNA and remaining as latent. Then, it became proviral DNA in an unexpressed condition with a low level of viral replication, which leads to undetectable viral RNA in plasma. However, negative for viral RNA and proviral DNA could be false negative from a primer failure. The gag sequences vary among strains circulating in Thailand when compared with various strains from many parts of the world. Gag sequence variation of EIAV as observed in our horses in this study revealed that variant of EIAV is prevalent among the asymptomatic carrier horses in Thailand. It possesses divergence in its gag sequence as compared to other strains of EIAV such as Liaoning strains, EIAV clone Ita-4, EIAV clone Rom-2, and EIAV Can-7 [7, 8]. The gag sequences of Tha1-Tha3 from this study showed approximately 69\% nucleotide sequence homology with Asian strains (EIAVv26, EIAVv70, and EIAVlia) and various EIAV clones (clone Ita-4, Rom-2, and Can-7) from Italy, Romania, and Canada (data not shown). This is the first report of gag gene sequences of EIAV from horses in Thailand.

Coggins test might give false positive results if the horses were exposed to some related retroviruses. The gag gene protein determinants are conserved among different viral isolates and between retroviruses in general. It probably is the vital protein for viral function $[9,10]$. Many studies [11, 12] have revealed the cross-reactivity between the major core protein of HIV and the analogous protein of EIAV, SIV, and the bovine immunodeficiency-like virus. The antigen used for Coggins test, prepared from spleens of infected animals or equine dermal cell cultures, might be contaminated with other cellular or host derived proteins rendering non-specific precipitin lines.

In conclusion, nested PCR, amplifying p26 gag genes of EIAV, are likely to be useful for the diagnosis of asymptomatic infected horses, especially at the early stage of infection where plasma associated viremia levels are usually at their highest levels and before the development of detectable antibodies. Gag gene sequences vary significantly among strains circulating in Thailand compared with various strains from many parts of the world.

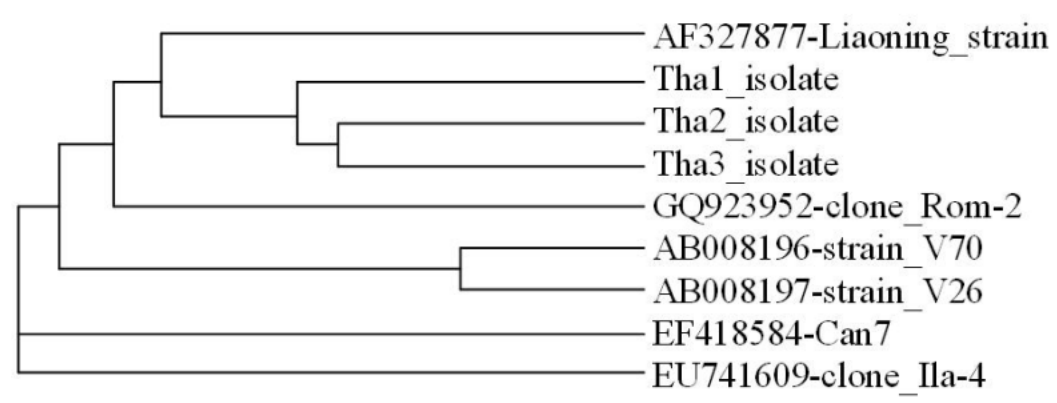

Fig. 1 Phylogenetic tree of three isolates (Tha1, Tha2, and Tha3) from this study were compared with other EIAV strains reported on NCBI GenBank such as Liaoning strain, EIAV clone from Romania, EIAV strains in Japan (V70 and V26), EIAV clones from Canada and Italy. 


\section{Acknowledgements}

We would like to thank Dr. Jodi Craigo from the University of Pittsburgh, Dr. Kenji Murakami from National Institute of Animal Health, Japan, and Dr. Jianhua Zhou from Chinese Academy of Agricultural Sciences, PR China for supporting DNA positive control and primer information. We also thank the staff of our Horse Farm-Laboratory and Animal Breeding Center for collecting blood samples.

We have no conflict of interest to report.

\section{References}

1. Sellon DC, Fuller FJ, McGuire TC. The immunopathogenesis of equine infectious anemia virus. Virus Res. 1994; 32:111-38.

2. National Institute of Animal Health. On line available from: http://www.did.go.th/dcontrol/activity/traininghorse/document3/eia.pdf

3. Coggins L. Carriers of equine infectious anemia virus. JAMA. 1984; 184:279-303.

4. Langemeier JL, Cook SJ, Cook RF, Rushlow KE, Montelaro RC, Issel CJ. Detection of equine infectious anemia viral RNA in plasma samples from recently infected and long-term inapparent carrier animals by PCR. J Clin Microbiol. 1996; 34:1481-7.

5. Spyrou V, Papanastassopoulou M, Psychas V, Billinis Ch, Koumbati M, Vlemmas J, et al. Equine infectious anemia in mules: virus isolation and pathogenicity studies. Vet Microb. 2003; 95:49-59.

6. Harrold SM, Cook SJ, Cook RF, Rushlow KE, Issel CJ,
Montelaro RC. Tissue sites of persistent infection and active replication of equine infectious anemia virus during acute disease and asymptomatic infection in experimentally infected equids. J Virol. 2000; 74: 3112-21.

7. Quinlivan M, Cook RF, Cullinane A. Real-time quantitative RT-PCR and PCR assays for a novel European field isolate of equine infectious anemia virus based on sequence determination of the gag gene. Vet Rec. 2007; 160:611-8.

8. Cook RF, Cook SJ, Li F, Montelaro RC, Issel CJ. Development of a multiplex real-time reverse transcriptase-polymerase chain reaction for equine infectious anemia virus (EIAV). J Virol Methods. 2002; 105:171-9.

9. Leroux C, Cadore JL, Montelaro RC. Equine infectious anemia virus (EIAV): what has HIV's country cousin got to tell us? Vet Res. 2004; 35:485-512.

10. Cullinane A, Quinlivan M, Nelly M, Patterson H, Kenna $\mathrm{R}$, Garvey M, et al. Diagnosis of equine infectious anemia during the 2006 outbreak in Ireland. Vet Rec. 2007; 161:647-52.

11. Oaks JL, Mcguire TC, Ulibarri C, Crawford TB. Equine infectious anemia virus is found in tissue macrophages during subclinical infection. J Virol. 1998; 72:7263-9.

12. Nagarajan MM, Simard C. Detection of horses infected naturally with equine infectious anemia virus by nested polymerase chain reaction. J Virol Methods. 2001; 94: 97-109. 